\section{Chefia indígena, política indigenista e missões religiosas: a perda do carisma de xamãs Kaiowá e Guarani na reserva multiétnica de Dourados, MS (1917-1980) Indigenous leadership, indigenous policy and religious missions: the loss of charism guarani kaiowá shaman in the multiethnic area in Dourados, MS (1917-1980)}

Lígia Duque Platero*

Resumo: Neste artigo, abordo o problema da perda do carisma de xamãs Kaiowá e Guarani na reserva de Dourados, no Mato Grosso do Sul, entre 1917 e 1980. A temática se associa à questão da aliança política e religiosa entre os Terena e parentelas Guarani-Kaiowá e Guarani-Ñandeva, com a Missão Evangélica Presbiteriana Caiuá (MEC). Neste texto, mostro que vários elementos da política indigenista do Serviço de Proteção ao Índio (SPI) e da Fundação Nacional do Índio (FUNAI), em associação à MEC, contribuíram para a diminuição da presença de xamãs na reserva indígena de Dourados (RID)como lideranças carismáticas, que exerciam o lugar de chefia política e religiosa. Entre esses elementos, destaco a política de terras do Estado brasileiro, a criação da figura do capitão, a existência de comunidades que se opunham politicamente (em facções) dentro da reserva e o desmatamento. Além disso, destaco situações de violência simbólica e física contra os praticantes da "religião tradicional" dos Kaiowá e Guarani da reserva de Dourados, nas décadas de 1960 e 1970, associadas a acusações de feitiçaria. Essas situações podem ser consideradas como casos de intolerância religiosa. O artigo se insere nos campos da Etnohistória, Antropologia Política e Antropologia da Religião.

Palavras-chave: Guarani-Kaiowá e Guarani-Ñandeva; intolerância religiosa; xamãs.

Abstract: In this article, I discuss the problem of loss of charisma Guarani Kaiowá shaman and on the Dourados reserve in Mato Grosso do Sul, between 1917 and 1980. The topic is associated with the issue of religious and political alliance between the Terena and kinsfolk
* Doutoranda em Antropologia do Programa de Pós-graduação em Sociologia e Antropologia (PPGSA) da UFRJ. Bolsista CAPES. Mestre em Estudos Latino-americanos pela Universidade Nacional Autônoma do México (UNAM). Bacharel e licenciada em História pela USP. E-mail: ligiaplatero@gmail.com
Tellus, ano 15, n. 28, p. 43-63, jan./jun. 2015

Campo Grande, MS 
Guarani-Kaiowá and Guarani-Ñandeva with the Missão Evangélica Presbiteriana Caiuá (MEC). In this paper, I show that various elements of the indigenous policy of the Serviço de Proteção ao Índio (SPI) and the Fundação Nacional do Índio (FUNAI), in association with MEC, contributed to the reduction of the presence of shamans in RID as charismatic leaders, who exercised the place of political and religious leadership. Among these elements, highlight the land policy of the Brazilian government, the creation of the captain's figure, the existence of communities that are politically opposed (in factions) within the reserve and deforestation. Also, highlight situations of symbolic and physical violence against practitioners of "traditional religion" of the Guarani Kaiowá and the Dourados reservation, in the 1960s and 1970s, associated with witchcraft accusations. These situations can be considered as cases of religious intolerance. The article falls in the fields of Ethnohistory, political anthropology and religion anthropology.

Key words: Kaiowá and Guarani; religious intolerance; shamans.

\section{Introdução}

Neste artigo, mostro elementos da política indigenista do Serviço de Proteção ao Índio (SPI) e da Fundação Nacional do Índio (FUNAI), em associação com a Missão Evangélica Caiuá (MEC), os quais produziram a perda do carisma dos xamãs "tradicionais" na reserva indígena de Dourados (RID), no período entre 1917 a 1980. Por que houve a diminuição da presença da liderança carismática dos rezadores na RID, no período entre a criação da reserva, em 1917, até o período quando as igrejas evangélicas pentecostais começaram a ingressar nessa Terra Indígena, em 1980? Pereira $(2004,2012)$, Vietta e Brand (2004) e Mura (2006) afirmaram que parte dos moradores da reserva acredita que os rezadores "não curam mais" e que, na reserva, "não há mais ñanderú de verdade". Neste artigo, apresento possíveis razões para essa transformação da chefia política e religiosa na RID.

Abarco o período da formação da reserva, em 1917, até 1980, para pensar sobre as relações e processos que podem ter gerado a transformação em relação à chefia espiritual e política na reserva. Essa transformação se deu com a presença dos capitães, e com a presença de novas lideranças indígenas políticas e espirituais, a partir da década de 1980, quais sejam os pastores evangélicos. No caso da Terra Indígena de Panambizinho, Souza (2012) chamou essa crise de "enfraquecimento da figura do rezador". A presença civilizadora da MEC nessa reserva, desde 1929, possui importância fundamental nesse processo.

Para abordar essas questões, baseei-me em discussão bibliográfica, em observação participante, realizada em um trabalho de campo exploratório na reserva de Dourados, com duração de um mês, entre novembro e dezembro de 2010, e entre 21 a 30 de março de 2015; além da análise do conteúdo de 
seis entrevistas em profundidade ${ }^{1}$ e na crítica documental (BLOCH, 2001) de quatro documentos escritos ${ }^{2}$, cuja análise foi feita por meio da crítica desses documentos históricos (BLOCH, 2001; RICOEUR, 2003).

Estabeleci um tipo ideal das relações entre pastores e xamãs, chefes de posto e capitães indígenas, visando entender como essas relações influenciaram na transformação da posição política dos xamãs "tradicionais". Utilizei o conceito de Max Weber (2012) de carisma, para pensar a questão da chefia na reserva.

Percebi que a aliança política e religiosa de parentelas Terena, Kaiowá e Guarani (Ñandeva) à Missão Evangélica Caiuá até a década de 1960 não foi o único elemento que levou os ñanderú e/ou rezadores Kaiowá e Guarani a diminuírem a realização de seus rituais tradicionais na RID, apesar da postura dos missionários da MEC, de inibir a realização de rituais "tradicionais", desde sua entrada na reserva até a década de 1980. De acordo com relatos de pessoas Guarani (Ñandeva), ainda que os pastores presbiterianos da MEC aconselhassem os fiéis a não participarem dos rituais tradicionais, afirmando que era "coisa do diabo", muitos Kaiowá e Guarani continuavam participando de ambos os tipos de cerimônias religiosas.

Por outro lado, de acordo com informantes, a derrubada da floresta na reserva, a partir da década de 1950, impossibilitou a presença e conexão com os espíritos da floresta, os-jara (donos), donos das árvores e dos animais, levando a uma transformação do xamanismo "tradicional" dos Kaiowá e Guarani (Ñandeva).

Além disso, nas décadas de 1960 e 1970, a política de terras do Estado brasileiro gerou a entrada compulsória de muitas parentelas Kaiowá e Guarani na reserva, principalmente a partir da década de 1960. Com a entrada de várias famílias extensas de Kaiowá e Guarani (Ñandeva) na reserva, estas passaram

\footnotetext{
${ }^{1}$ Para preservar os interlocutores, a maioria dos nomes dos entrevistados foi ocultada ou alterada. As entrevistas utilizadas foram realizadas com uma professora Kaiowá, uma professora Guarani (Ñandeva), um idoso Guarani (Ñandeva), um reverendo da Missão Caiuá e uma rezadora Guarani (Ñandeva). Além dessas entrevistas, utilizei trechos de uma entrevista realizada por Santos (2012). Sendo a maioria dos interlocutores Guarani-Ñandeva, este artigo explicita a memória de membros dessa etnia em relação a eventos ocorridos sobretudo nas décadas de 1960 e 1970, na RID.

${ }^{2}$ Os documentos utilizados foram os seguintes: MISSÃO EVANGÉLICA CAIUÁ - MEC. Associação Evangélica de Catequese dos Índios. Biblioteca Marechal Rondon. Rio de Janeiro: Museu do Índio/FUNAI, [s.d.]; SUMMER INSTITUTE OF LINGUISTICS. Relatório das atividades dos membros do "Summer Institute of Linguistics" entre os índios brasileiros no ano de 1959, dirigido ao diretor do Serviço de Proteção aos Índios. Rio de Janeiro: Museu do Índio/FUNAI. Microfilme 338, fotograma 881 - 893, 1960; SPI, Sobre ministração de escola e cultos religiosos, 1953, Microfilme 380, fotograma 1507; SPI, Separata do regulamento do Serviço de Proteção aos Índios relativa aos Postos Indígenas - decreto n. 736 de 5 de abril de 1936, microfilme 338, fotograma 2274b, p.15.
} 
a se organizar em relações de alianças e oposições entre parentelas, gerando o que Thomaz de Almeida (2001) chamou de faccionalismo.

O ideal de vida dos Kaiowá e Guarani é a existência de cada família extensa em seu tekoa, sendo as parentelas lideradas pelos cabeças de parentela, cujo ideal de vida é a consanguinidade (e a consanguinização dos afins por meio da coabitação). Com a coexistência de várias parentelas dividindo espaço na mesma reserva, essas facções agem por meio do que os Kaiowá e Guarani chamam de política (THOMAZ DE ALMEIDA, 2001), associada a fofocas e boatos (e acusações de feitiçaria), sendo que cada um visa sempre à proteção dos interesses de sua própria parentela ou parentelas aliadas.

A presença de diferentes comunidades de Terenas, Kaiowás e Guaranis (Ñandeva) na reserva possibilitou a existência de casamentos interétnicos, gerando comunidades multiétnicas hierarquizadas, com um vasto leque de distintividades culturais (PEREIRA, 2012).

De acordo com relatos de Guaranis (Ñandeva), a ação dos capitães Terena nas décadas de 1960 e 1970 foi muito violenta, marcada pelo apoio da MEC e do SPI e da FUNAI (existente a partir de 1967). Entre essas comunidades, a maioria Terena da aldeia Jaguapirú foi a que mais se aliou à MEC. O apoio dado pela MEC às famílias de capitães terena significou uma amplificação das acusações de feitiçaria e da perseguição política contra os xamãs e pessoas que participavam das práticas religiosas "tradicionais".

De acordo com Thomaz de Almeida (2001 apud MURA, 2010), as afirmações dos pastores da MEC de que as práticas religiosas dos xamãs tradicionais eram "coisas do diabo" resultaram na amplificação das acusações de feitiçaria entre parentelas rivais, ampliando as lutas internas na RID. Essas afirmações dos missionários de que as cerimônias dos Kaiowá e Guarani eram diabólicas podem ser consideradas como casos de violação de direitos à liberdade religiosa ou casos de intolerância religiosa ${ }^{3}$. É possível que, nessas décadas,

${ }^{3}$ De acordo a Miranda (2010), a intolerância religiosa é uma categoria moral fortemente usada
pela Comissão de Combate à Intolerância Religiosa (CCIR). Essa comissão foi criada em 2008
como reação às ações violentas de neopentecostais contra terreiros de candomble e umbanda
no Rio de Janeiro. Segundo Silva (2009), a intolerância religiosa assemelha-se à discrimina-
ção em geral, associada ao preconceito étnico e racial, como atitude em face ao "outro". De
acordo a Miranda e Goulart (2009), o tema da tolerância faz parte da construção simbólica da
sociedade ocidental, representando a tentativa de tratar por meio de acordos públicos a cisão
e a diferença. John Locke (1964, apud MIRANDA; GOULART, 2009) afirmou em sua Carta a
respeito da tolerância que o "problema da intolerância" resultava da confusão entre os domínios
civil e religioso. Nessa carta, o autor estabelece o princípio da laicidade do Estado moderno,
ao afirmar que "pessoa alguma tem o direito de prejudicar de qualquer maneira a outrem em
seus direitos civis por ser de outra igreja ou religião". À luz da legislação brasileira, a intole-
rância religiosa correspondia, até abril de 2014 , à infração da legislaçâo antirracismo no que
diz respeito à liberdade de culto e de crença. A lei antirracismo é a Lei Caó, n.7.716/89, que carisma de xamãs Kaiowá e Guarani na resenva multiétnica de Dourados, MS (1917-1980) 
alguns xamãs tenham se retirado da reserva para evitar maiores conflitos, após violências simbólicas e físicas associadas a acusações de feitiçaria.

Assim, a perda do carisma dos ñanderú ou rezadores foi gerada devido à confluência de vários fatores que alteraram a presença da chefia indígena tradicional. Entre esses fatores, destacam-sea política de terras do Estado brasileiro, que gerou o confinamento; a criação pelo SPI e FUNAI da figura política do capitão, que foi incorporado às práticas políticas das comunidades inseridas na RID; o desmatamento, que levou à expulsão dos espíritos donos dos animais e da floresta, segundo a cosmologia dos Kaiowá e Guarani (Ñandeva), impossibilitando práticas do xamanismo "tradicional" e a comunicação com as divindades. Além disso, a existência de disputas entre comunidades rivais dentro da RID, intensificadas devido ao apoio da MEC no combate às práticas religiosas dos ñanderú, desde sua inserção na reserva em 1929 até a década de 1980, também foi um fator muito importante para a perda do espaço político e do carisma dos rezadores. Entretanto, na década de 1980, a MEC iniciou uma autocrítica em relação a suas práticas e alterou o seu discurso, já não tão contrária às práticas religiosas dos xamãs.

\section{A política indigenista e a reserva de Dourados}

Entre 1915 e 1928, o SPI criou sete reservas indígenas ${ }^{4}$ no atual Mato Grosso do Sul, destinadas à ocupação dos Kaiowá, visando à "proteção" e à "civilização" dos indígenas e à abertura de territórios tradicionalmente indígenas para a ocupação de colonos brasileiros. A Reserva Indígena de Dourados foi criada em 1917, com 3600 ha, junto ao Posto Indígena Francisco Horta, como Posto de Assistência, Nacionalização e Educação. As áreas reservadas pelo SPI não eram os lugares onde se instalavam tradicionalmente as famílias extensas dos Kaiowá. Estas habitavam tradicionalmente os tekoa, lugares onde se constrói o modo de ser Kaiowá e Guarani.

Nessas unidades familiares, os ñanderú eram tradicionalmente os guias espirituais e a autoridade política principal. Eles eram líderes carismáticos,

vigora hoje em sua quarta versão (SILVA, 2009, p.27). Entretanto, além dessa lei, atualmente vigora a Lei de Ação Civil Pública, n. 12.966, de 24 de abril de 2014, com a inclusão da proteção à honra e dignidade de grupos raciais, étnicos ou religiosos.

${ }^{4}$ A primeira foi a reserva Benjamim Constant, criada em 1915, em Amambaí, com 3.600ha. A segunda, criada em 1917, foi a reserva de Dourados, com 3.600ha. A terceira foi a reserva Caarapó, de 1924, com uma extensão de 3700 ha. Em 1928, foram criadas mais quatro reservas: a reserva Limão Verde, em Amambai, com 900 ha, e as reservas Pirajuy, em Paranhos, Sassoró/ Ramada, em Tacuru e a reserva de Tacuaperi, em Coronel Sapucaia, todas com 3600ha cada (BRAND, 1997). 
cuja autoridade era baseada em conhecimentos e conselhos, não sendo uma autoridade coercitiva (SHADEN, 1962).

Desde a formação do Posto Indígena Francisco Horta, o SPI criou a figura do capitão na reserva, indígena escolhido pelo SPI para ser uma autoridade e um intermediário entre as parentelas e os chefes de Posto. De acordo com interlocutores indígenas, os capitães não eram uma figura política importante desde a criação da reserva até a década de 1950. Entretanto, a partir das décadas de 1950 e 1960, a sua presença política e coercitiva começou a ofuscar a liderança dos xamãs.

Desde a década de 1920, parentelas Terena foram levadas pelo SPI para ocupar a reserva de Dourados junto aos Kaiowá, pois eles eram considerados mais "civilizados" porque falavam português, eram produtores rurais e haviam lutado junto aos brasileiros na Guerra do Paraguai. A entrada dos Terena na reserva foi parte do projeto de nacionalização do SPI. Parentelas Guarani (Ñandeva) também passaram a habitar a reserva, muitas delas vindas do Paraguai ou de outras localidades.

Além da presença dos capitães indígenas na reserva, desde 1928 havia também a presença carismática dos pastores da presbiteriana $\mathrm{MEC}^{5}$. Eles foram autorizados pelo SPI a ingressar na reserva, pois a política indigenista do SPI de "civilização" ou nacionalização considerava que a conversão religiosa ao cristianismo poderia ser uma maneira exitosa de incorporação dos indígenas à sociedade brasileira ${ }^{6}$. Os missionários receberam autorização para utilizar o edifício escolar do Posto como escola diária da missão e para realizarem reuniões dominicais (LOURENÇO, 2008, p.134).

Estou de acordo com Lourenço (2008, p.134), quando afirma que houve uma confluência entre a política indigenista realizada pelo SPI e o trabalho da $\mathrm{MEC}^{7}$. A assistência nas áreas de educação e saúde foi o foco do trabalho da

${ }^{5}$ Os fundadores da MEC eram o reverendo Alberto Sydnei Maxwell e sua esposa Mabel Davis Maxwell. Eles eram missionários presbiterianos estadunidenses que representavam a East Brazil Mission (LOURENÇO, 2008).

6 Durante a formação do SPI, houve um processo de laicização da questão indígena no país (ROCHA, 2003, p.147). Entretanto, pode-se perceber que, principalmente a partir da década de 1930, as igrejas foram consideradas como instrumento de "incorporação" e "civilização" das populações indígenas, ainda que tivessem que seguir as normas estabelecidas pela política indigenista oficial. No regulamento do SPI de 1936, esta questão fica explicitada: “Os índios são também inteiramente livres, quando queiram, de guardar e praticar as crenças e ritos de seus maiores, e com eles atingir a incorporação à nacionalidade" (SPI, Separata do regulamento do Serviço de Proteção aos Índios relativa aos Postos Indígenas - decreto n. 736 de 5 de abril de 1936, microfilme 338, fotograma 2274b, p.15).

${ }^{7}$ De acordo com Miranda (2010), a separação oficial entre Estado e Igreja nos remete à promulgação da primeira Constituição da República, de 24 de fevereiro de 1891, que aboliu a religião carisma de xamãs Kaiowá e Guarani na resenva multiétnica de Dourados, MS (1917-1980) 
MEC, visando à mudança de costumes e à conversão religiosa dos indígenas da reserva, no sentido de conversão no âmbito das crenças. Como afirma uma interlocutora Guarani (Ñandeva), “O ensino do português na escola estava diretamente relacionado com a catequização, pois o objetivo era ensinar a ler a bíblia".

A MEC realizava um trabalho assistencialista distribuindo roupas, remédios e ensinando as primeiras letras e hábitos de higiene aos indígenas. Além disso, a Missão criou, em 1938, o orfanato Nhanderoga, onde se instalavam os filhos órfãos dos indígenas da região. No Nhanderoga, a antiga prática missionária de educação das crianças indígenas como foco principal para a conversão religiosa persistia, na longa duração: "É na criança índia que a Missão deposita as suas mais ricas esperanças" (MEC, s.d., p. 04).

De acordo com outra interlocutora Guarani (Ñandeva):

Era um internato onde a missão Kaiowá criou tipo um orfanato. Tinha muitas crianças que perderam os pais, ficaram órfãos no período da epidemia de febre amarela, sarampo, catapora e varíola que se abateu aqui na comunidade. Muitas crianças ficaram órfãs, aí a missão criou em Nhanderoga, que é a nossa casa em Português.

As mortes devido às epidemias e as curas alcançadas com a utilização de remédios da medicina ocidental davam margem a ideias de que "a missão ajuda o índio". Já nas primeiras décadas da presença da Missão na reserva, muitas parentelas se aproximaram dos pastores que, como os xamãs, também eram conselheiros, curadores e líderes carismáticos.

Em 1941, existiam duas escolas na reserva de Dourados, ambas na aldeia Jaguapirú. Uma era a escola do Posto, e a outra era a Escola da Missão. De acordo com interlocutores, essas escolas eram a escola da Missão era "igual à escola de branco", com as mesmas disciplinas. O principal ponto curricular nas escolas era o ensino do português, junto ao ensino de hábitos associados à higiene, ao uso de roupas regionais, o combate ao alcoolismo e a crença no trabalho produtivo.

Entre as atividades da MEC, eram realizados aos domingos atos cívicos, nos quais se levantava a bandeira e se cantava o hino nacional, além de

oficial no país "ao afirmar que "todos os indivíduos e confissões religiosas podem exercer pública e livremente o seu culto, associando-se para esse fim e adquirindo bens, observadas as disposições do direito comum" ( $\$ 3^{\circ}$ do art. 72, Seção II - Declaração de Direitos)" (MIRANDA, 2010, p.127). Entretanto, como afirma a autora, "o primeiro marco legal republicano que entrou em vigor foi o Código Penal, de 11 de outubro de 1890, no qual estava prevista a criminalização de algumas práticas não classificadas como "religiosas", mas que eram associadas aos crimes contra a saúde pública e ao exercício ilegal da medicina" (MIRANDA, 2010, p.127). Sendo assim, as práticas que não se enquadravam à concepção da prática religiosa vigente (cristã), com direito à proteção legal, ganhavam uma distinção de status, podendo ser criminalizadas. 
executar rituais e cerimônias religiosas cristãs, configurando uma unidade entre rituais cívicos nacionais e religiosos (SPI, Sobre ministração de escola e cultos religiosos, 1953, Microfilme 380, fotograma 1507). Na década de 1950, os principais trabalhos da Missão associavam-se à Escola primária (Escola da Missão), o orfanato Ñhanderoga, o ambulatório médico e a Igreja Evangélica Caiuá (com uma escola dominical, com 150 alunos, divididos em oito turmas). A Missão também possuía duas escolas na matas e cincopontos regulares de pregação (MEC, s.d., p. 05).

\section{Os significados da conversão religiosa}

Desde a entrada da Missão Evangélica Caiuá na Reserva, em 1928, até a década de 1980, a conversão religiosa ao protestantismo histórico de algumas parentelas Kaiowá e Guarani e também de parentelas terena significava fazer parte de um grupo de convívio e solidariedade, que possibilitava receber auxílios materiais relacionados com a assistência educativa e ajuda na área da saúde e no orfanato. De acordo com entrevista realizada com uma professora Guarani (Ñandeva), como uma espécie de contrapartida à ajuda da missão, as famílias participavam dos cultos e frequentavam os pontos de pregação.

A presença dos pastores da Missão dentro da Reserva de Dourados, nesse período, gerou uma alternativa à autoridade carismática dos chefes de parentela e xamãs, que indicavam os costumes e a forma adequada de ser. Entretanto, não havia brigas entre pastores e xamãs, existindo em geral relações respeitosas e cordiais.

O que movia o trabalho dos obreiros da Missão Caiuá era a fé que tinham na necessidade da cristianização das populações indígenas Kaiowá e Guarani. Aos olhos dos pastores, a vida dos indígenas com poucos recursos materiais, com doenças e privações era a expressão da falta de Deus em suas vidas. Ainda que a assistência educacional e de saúde fossem pontos fortes do trabalho da Missão de mudança de costumes, o seu principal objetivo seguia sendo a catequização ${ }^{8}$. O tripé do trabalho da missão era a catequização na igreja, o ensino religioso e o atendimento ambulatorial (MEC, s.d., p.05).

Desde as primeiras décadas da permanência da Missão na reserva de Dourados, os Kaiowá e os Guarani estiveram disponíveis e quiseram participar das atividades escolares do SPI e da Missão e das reuniões dominicais

\footnotetext{
${ }^{8}$ A temática da associação entre o projeto de mudança de costumes e "conversão religiosa" é uma continuidade da longa duração. O projeto de catequização dos jesuítas foi, desde o século XVI, um projeto de transformação dos maus costumes (VIVEIROS DE CASTRO, 2013).
} 
de catequização. Essa "abertura ao outro" dos Kaiowá e Guarani para a participação nas atividades da Missão se dava porque a língua portuguesa, a bíblia e os rituais cristãos eram compreendidos como poderes dos brancos, que eram almejados por muitos indígenas.

Como afirma Viveiros de Castro (2013, p. 195), a busca de absorver o outro é uma constante em meio à inconstância da alma selvagem ${ }^{9}$. O problema é perceber o significado desse "crer sem fé", esse obscuro desejo de ser o outro, mas segundo os próprios termos.

Como afirma Benites (2009), a frequência à escola foi estimulada por muitas parentelas Kaiowá, pois a escrita e a escolarização eram consideradas fontes de saberes externos, prestígio e poder político dos não indígenas. Por isso a aprendizagem da escrita foi, muitas vezes, desejada e estimulada pelas famílias dos Kaiowá, dos Guarani e dos Terena.

De acordo com interlocutores, muitas parentelas Kaiowá e Guarani estimulavam seus filhos a participarem das atividades escolares. Como afirmou a professora Marlene Guarani (entrevista de 2010) ${ }^{10}$, que iniciou seus estudos em 1957,

Era uma coisa nova que tinha na aldeia -, e os pais queriam que os filhos lessem. [...] eles deixavam ir à escola, porque era uma coisa nova e falava que o filho ia aprender ler. E outro que a missão veio pregar uma religião e o índio Kaiowá sempre frequentou a igreja e frequentou a escola também.

Além do ensino do português, a MEC também buscou cristianizar por meio do ensino bilíngue. Na década de 1950, a MEC aliou-se à missão protestante Summer Institute of Linguistcs (SIL). Junto ao Summer, os pastores realizaram um trabalho de tradução da bíblia e de criação de cartilhas. Diversos indígenas participaram desse processo, entre eles, o Kaiowá Marçal de Souza. Primeiramente, as cartilhas foram usadas por professores não indígenas na Reserva. Como afirmou uma interlocutora Guarani (Ñandeva), esse ensino era algo como "faz de conta que eu ensino e faz de conta que eu aprendo".

Além da alfabetização associada à catequização, que era realizada nas escolas, a Missão possuía outras formas de expansão do evangelho na reserva. Em documento (MEC, s.d.), a missionária Dona Loide conta sobre uma convenção evangélica realizada entre 15 e 16 de agosto de 1951, com a

\footnotetext{
${ }^{9}$ Como afirma Viveiros de Castro (2013, p. 195): “O problema, portanto, é determinar o sentido desse misto de volubilidade e obstinação, docilidade e recalcitrância, entusiasmo e indiferença com que os Tupinambá receberam a boa-nova. É saber o que eram essa "fraca memória" e essa "deficiência da vontade" dos índios, esse crer sem fé; é compreender, enfim, o objeto desse obscuro desejo de ser o outro mas, este o mistério, segundo os próprios termos".
}

${ }^{10} \mathrm{O}$ nome da entrevistada foi alterado. 
presença de crentes e missionários da South American Indian Mission. Um dos objetivos da reunião era "despertar as igrejas indígenas para a evangelização dos seus irmãos".

De acordo com o relato da missionária Dona Loide, naquela reunião, o capitão da aldeia Bororó da reserva de Dourados dirigiu-se para lá com trinta pessoas Kaiowá, que não falavam português. Uma estratégia dos missionários era traduzir as pregações para as línguas terena e guarani e, naquela ocasião, houve tradução para essas duas línguas.

Para a missionária, os momentos mais emocionantes daquele encontro foram os indígenas Kaiowá ao falarem publicamente e "se entregarem para Cristo". Exponho a seguir a fala de um Kaiowá, segundo o relato da missionária:

Eu não tenho nada, sou muito pobre, nem a minha família eu trouxe comigo, mas viajei dia e noite sem parar para assistir esta reunião. Não tenho nada para dar a Jesus, mas dou a ele hoje o meu coração, quero segui-lo sempre, estou encantado em ver tanta gente. (MEC, s.d., p.05).

A adoção do cristianismo nesse contexto se associava a fazer parte de um grupo de solidariedade. Nessa fala de um Kaiowá, é perceptível a adoção do discurso da Missão Caiuá sobre a miséria dos indígenas. De acordo com os pastores da Missão, a miséria material era expressão da miséria espiritual. Com esse discurso sobre a miséria e ausência de Deus, a Missão justificava a sua atuação junto aos indígenas e junto aos fiéis das igrejas financiadoras (GONÇALVES, 2012).

De acordo com a missionária, entre todos os que falaram, o momento que gerou mais alegria foi na fala de Marçal de Souza. Segundo ela, ele subiu no púlpito onde estava o reverendo Orlando e falou: "Reverendo, o senhor tem trabalhado sozinho, mas de hoje em diante, eu estarei ao seu lado em todo o Serviço do Senhor e em todas as lutas, eu não tenho feito nada pelo meu Mestre e agora Ele me chama, eu irei, nem que seja para sofrer ou morrer por Ele".

Ele se tornou a primeira liderança indígena letrada na aldeia, na década de 1950. De acordo com uma interlocutora, Marçal de Souza foi uma liderança que frequentava a Missão e os cultos. Ele foi o primeiro indígena da reserva a se tornar professor e catequista ${ }^{11}$.

De acordo com a fala da professora Guarani (Ñandeva) Edna Guarani (SOUZA, 2012),

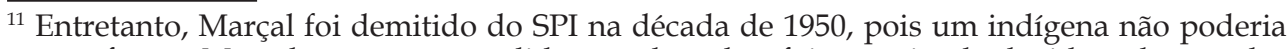
ser professor. Marçal se tornou uma liderança letrada e foi assassinado devido às lutas pelas terras, no dia 25 de novembro de 1983. 
Nós aqui da minha família, nós fomos educados na igreja Presbiteriana que é a da Missão Caiuá. Meu pai [Marçal de Souza] chegou a fazer o curso de missionário, e a gente nasceu e foi criado na religião cristã e vendo como se vivia nessa outra crença. Mas, paralelo a isso, meu pai sempre explicava e mostrava que a gente tinha outro tipo de crença, do índio mesmo, e que os ensinamentos da Missão eram a crença do não índio. Contudo, a maioria de nós indígenas, como a missão era coisa nova, ia por necessidade material ou pelo medo da igreja.

Como percebido nas falas de interlocutores, o trabalho da Missão Caiuá possuía um aspecto persuasivo, devido ao seu persistente trabalho de assistência e à criação de uma visão generalizada na reserva de que "a missão ajuda o índio". Entretanto percebi, na fala dos interlocutores, que os pastores da MEC também realizavam ameaças para que os frequentadores de seus cultos não participassem mais das práticas rituais tradicionais, associando-as a "coisas do diabo" e ao pecado.

Como afirmou uma interlocutora Guarani (Ñandeva) (entrevista de 2010), os pastores proibiam a participação dos “fiéis" Kaiowá e Guarani nas cerimônias religiosas tradicionais: "proibia, falava que era pecado, que era coisa do diabo, que tinha que seguir a religião de Jesus". Essa postura da Missão fazia com que algumas parentelas deixassem de participar das cerimônias religiosas e dos rituais tradicionais dos ñanderú.

Portanto houve uma espécie de comparação e competição entre as lideranças carismáticas dos pastores da missão e dos xamãs tradicionais. Lembrando que esses dois atores religiosos eram também lideranças políticas importantes na reserva. Como líderes carismáticos, a sua presença e suas falas continham exemplos sobre "a boa maneira de se viver".

De acordo com Edna Guarani, muitas parentelas seguiam frequentando os dois tipos de culto, o cristão e as cerimônias de chicha tradicionais. Entretanto algumas famílias ficavam amedrontadas e já não participavam das cerimônias de chicha:

[...] uns deixavam de ir porque tinham medo, porque a religião dizia que era pecado, as festas tradicionais eram pecado, eram coisa do diabo e quem fazia isso ia sofrer penalização, ia para o fogo do inferno. E tanto que o fogo é sagrado para nós, olha que contradição.

De acordo com Mura (2006), as afirmações dos pastores da MEC de que a religião dos Kaiowá e Guarani era "coisa do diabo" resultou na intensificação das acusações de feitiçaria entre os próprios indígenas. Por meio da observação e das entrevistas, percebo que a adoção da crença cristã, a participação dos cultos e o pertencimento a grupos aliados à MEC não significou a "perda da cultura", nas palavras de Terenas e Guaranis. Ainda que algumas parentelas ficassem com medo de participar dos rituais tradicionais, associando-os à 
possível execução de feitiços feitos pelos xamãs, muitos continuavam participando e a estrutura sociocosmológica persistia.

\section{Significados do feitiço, da cura e da doença para pastores e xamãs}

De acordo com Mura (2006), a feitiçaria é uma forma de predação no nível da magia. Muitos autores separaram a religião dos Guarani e dos Kaiowá da crença na magia. Entretanto, a magia e a religião são um só para os Kaiowá e Guarani. Na crença tradicional, a feitiçaria é uma prática que pode ser realizada por um xamã, mas que teve uma formação diferenciada, com o auxílio de seres telúricos e não somente de seres divinos.

Quando o doente respeita o teko porã (o bom viver), as doenças poderiam ter sido transmitidas por outros xamãs, por meio da prática do feitiço. Para os Kaiowá e os Guarani, as doenças são problemas de desequilíbrio social (violência, homicídio, briga, etc.) provocados pela quebra de interditos (quando a pessoa não se comporta de acordo ao teko porã - a maneira certa de se viver). Mas muitos desses interditos deixaram de ser praticados com o contato com não índios e com as instituições da sociedade nacional na Reserva, porque a nova situação não viabilizava essa prática nas ações cotidianas e rituais que constituíam o teko porã.

Estou de acordo com Mura (2006, p. 267) ao afirmar que:

As doenças são associadas a anomias sociais, e os xamãs tradicionais afirmam que muitas doenças são resultado das experiências do teko reta, as múltiplas formas de ser Kaiowá. Quando uma pessoa não segue as normas tradicionais, os xamãs afirmam que a "culpa" para a existência da doença é o próprio doente.

Um exemplo dessa quebra de interditos é a mistura das crianças de parentelas diversas nas mesmas escolas. A educação das crianças, que era realizada pelas próprias parentelas, passou a ser realizada unindo as crianças de diferentes parentelas nos mesmos espaços, criando situações de brincadeiras e chacotas que eram desaconselhadas pelos mais velhos, guiados pelos aconselhamentos do xamã líder de parentela. As crianças também não podiam andar sozinhas nas estradas, o que passou a acontecer (BENITES, 2006).

De acordo com Mura (2006), para os xamãs Kaiowá, a cura era uma questão de equilíbrio e harmonia social. Quando uma pessoa adoece, os xamãs afirmam que isso é resultado das atitudes da pessoa, que não seguia o teko porã, o bom viver. Quando a pessoa seguia essa maneira de ser, os xamãs diziam que a doença podia ser resultado devido ao mau comportamento de outros 
familiares. Para os xamãs, o procedimento de cura se associava à capacidade do xamã de afastar os maus espíritos.

Para os pastores, as doenças eram resultado da miséria na qual viviam os Kaiowá Guarani, em uma situação "sem Deus no mundo". O significado da doença para os pastores é a debilidade do corpo físico, que pode ser contida com o uso de medicamentos. Em 1961, a Missão Evangélica Caiuá criou um Hospital, que representou um maior atrativo para a população da reserva em torno à Missão e aos pastores. Desde a década de 1930, os pastores de Missão Caiuá recebiam os Kaiowá e Guarani para tratá-los de tuberculose, devido à epidemia que havia na região (VIETTA, 2007).

Como diz a fala do reverendo Benedito, que também foi muito repetida por interlocutores terena, "se não fosse a Missão, muitos indígenas não estariam vivos, pois estavam todos doentes, e a Missão os ajudou a curar". Além disso, a missão ajudou a criar os filhos e filhas dos órfãos, o que comprova que "a missão ajuda o índio". Essa ajuda fazia com que a Missão se transformasse em um polo de atração dos Kaiowá e dos Guarani da reserva.

\section{O desmatamento}

Entre os fatores que levaram à perda de carisma dos ñanderú ou rezadores na reserva está o desmatamento, promovido pelo SPI desde a década de 1950, e prosseguido pela FUNAI na década de 1970. O desmatamento levou à transformação do modo de vida, inviabilizou um tipo de existência próximo aos espíritos da natureza e a manutenção de práticas cotidianas associadas à religião tradicional. $\mathrm{O}$ desmatamento ocorreu não apenas dentro da RID, mas também nas fazendas onde ainda viviam parentelas Kaiowá e Guarani.

De acordo com os interlocutores, era a conexão com a natureza que permitia aos indígenas vivenciarem a sua religião "tradicional". A presença da vegetação na reserva foi extinta na década de 1970:

Até na década de 70 ainda existia floresta, eu aqui, a gente foi criado totalmente em sintonia, em harmonia com a natureza, em todos os sentidos, a questão cultural religiosa indígena. (Entrevista de novembro de 2010).

De acordo com a entrevista a Edna Guarani realizada por Santos (2012, p. 207), as famílias se reuniam espontaneamente:

Aqui era floresta! [...] Então, a gente ia para as rezas, a chicha, as danças tradicionais e participava das reuniões de família, das histórias orais, da tradição.

Um interlocutor Terena (entrevista de 2010) afirmou que, até o começo da década de 1970, ainda existia muita peroba e aroeira na reserva. Mas a FU- 
NAI disse que iria derrubar as matas para "fazer casa para o índio". "Sempre aquela história de fazer para o índio, né? Mas pouco se faz para o índio, né?”.

\section{Política territorial e sobreposição de parentelas na RID}

Além da questão do desmatamento, de acordo com Brand (1997), o processo de esparramo foi mais intenso entre 1950 e 1980, gerando o que o autor chamou de confinamento. Essas décadas foram um período de criação de fazendas, e os Kaiowá foram sendo expulsos de suas aldeias, buscando refúgio no fundo das fazendas (onde havia floresta) e nas reservas (BRAND, 1997) ${ }^{12}$.

De acordo com Roberto Cardoso de Oliveira (1976 apud MURA, 2006), na década de 1950, havia, na reserva de Dourados, quatro comunidades, uma terena e outras três Kaiowá, cada grupo mantendo sua autonomia. A família mais influente era a Fernandes, seguida pela dos Snards, ambas Kaiowá.

Devido à entrada de um grande número de parentelas Kaiowá, Guarani e Terena na década de 1960, a situação transformou-se e acirraram-se os conflitos entre as parentelas. Com a entrada de várias famílias extensas de Kaiowá e Guarani (Ñandeva) na reserva, estas passaram a se organizar em relações de alianças e oposições entre parentelas, gerando o que Thomaz de Almeida (2001) chamou de faccionalismo. Com a coexistência de várias parentelas dividindo espaço na mesma reserva, essas facções agem por meio do que os Kaiowá e Guarani chamam de política (THOMAZ DE ALMEIDA, 2001), associada a fofocas e boatos (e acusações de feitiçaria), sendo que cada um visa sempre à proteção dos interesses de sua própria parentela ou parentelas aliadas.

De acordo Thomas de Almeida (2001 apud MURA, 2010), criou-se na década de 1960 uma tríade entre os capitães, os chefes de posto e os pastores, favorecendo a consolidação do papel do "capitão" indígena na RID. Essa tríade possibilitou que algumas famílias indígenas, principalmente terenas, pudessem sobrepor-se às famílias rivais.

\footnotetext{
${ }^{12}$ Alguns autores trataram do histórico do contato entre os Kaiowá, os Guarani e a sociedade nacional (BRAND, 1997; VIETTA, 2007), nessa região de fronteira entre os países Paraguai e Brasil. Esses autores associaram a questão do contato ao problema da perda da terra dos tekoa dos Kaiowá. Durante o Estado Novo, como parte da Marcha para o Oeste - uma campanha ideológica que previa a "construção da nação" e a colonização do "interior desabitado" do país - foram criadas várias Colônias Agrícolas Nacionais e, entre elas, a Colônia Agrícola Nacional de Dourados (CAND), criada em 1943 no território federal de Ponta Porã. Essas Colônias Agrícolas buscavam colonizar e nacionalizar o interior do país e as regiões de fronteira e formavam parte do Ministério da Agricultura, correspondendo ao plano de colonização do governo federal (BRAND, 1997, p.85). Assim, foi intensificado o processo de dispersão das parentelas e o desmantelamento das famílias extensas, em um processo chamado pelos Kaiowá de esparramo, segundo Brand (1997).
} carisma de xamãs Kaiowá e Guarani na resenva multiétnica de Dourados, MS (1917-1980) 
Segundo Thomas de Almeida (2001 apud MURA, 2010), entre os anos 1960 e 1970, as reservas tiveram a sua população duplicada ou mesmo triplicada. Famílias pertencentes a grupos políticos inimigos foram obrigadas a viver em pequenos espaços reservados:

Nessa situação, a eficácia da intervenção dos agentes coloniais aumentou, permitindo a construção de novas estruturas de poder que tiveram significativas consequências sobre a organização interna das reservas, favorecendo a consolidação do papel de "capitão" indígena, instituído pelo SPI para mediar as relações com essa população. (THOMAS DE ALMEIDA, 2001 apud MURA, 2010, p. 128).

De acordo com Mura (2006), essa articulação entre chefes de Posto, pastores da Missão Caiuá e "capitães", instaurou um clima de tensão e violência nas reservas. As famílias articuladas a esses capitães conseguiram diminuir a influência política dos xamãs. Nesse contexto, havia muitas acusações de feitiçaria, e as famílias tinham medo de desenvolver doenças que, supostamente, poderiam ser lançadas por feitiços:

Criava-se assim, uma tríade, composta por chefe de Posto, pastor e "capitão", que impunha regras políticas e lógicas de desenvolvimento alheias à tradição indígena. Isto ocorria muitas vezes porque, apoiadas nesse suporte externo, algumas famílias indígenas podiam exercer com maior eficácia poder sobre suas rivais, não significando que se teriam convertido ou assumido outra ótica comportamental. O fator cultural básico permanecia o mesmo, sendo que a acusação de práticas de feitiçaria (dirigida aos xamãs relacionados a famílias não aliadas), por exemplo, constituiu uma significativa arma nas mãos dos missionários, que conseguiram, por certo período, isolar os xamãs de muitas famílias, que temiam ser atingidas por doenças - estas sendo consideradas obra de algum feiticeiro. (MURA, 2006, p.128).

De acordo com entrevista de uma professora Guarani (Nandeva) e seu pai, habitantes da RID, havia um trauma de muitas famílias Kaiowá e Guarani em relação aos capitães terena, devido à sua atuação nas décadas de 1960 e 1970. Nesse período, "qualquer reza dos Kaiowá e dos Guarani eram consideradas como rezas para matar". As cerimônias religiosas dos Kaiowá e dos Guarani foram identificadas com feitiçaria, "como algo do diabo, como macumba". A fala dessa professora guarani é interessante, pois há a presença da ideia do senso comum da sociedade brasileira de que a "macumba" ou manifestações religiosas de origem africana são "coisas do diabo". Nesse sentido, as cerimônias religiosas dos Kaiowá e dos Guarani eram identificadas negativamente a religiões afro-brasileiras, sofrendo tipos comparáveis de violência simbólica.

De acordo com Mura (2006), a acusação da feitiçaria foi utilizada como uma arma significativa nas mãos dos missionários ou dos capitães. Havia a 
crença na Reserva de que as doenças poderiam ser provocadas por algum feiticeiro, e as cerimônias religiosas tradicionais e os rituais passaram a ser identificados à feitiçaria. Devido ao aumento do número de parentelas na reserva e a conflitos resultantes da divisão dos lotes entre as novas parentelas que chegavam, aumentavam também as acusações de feitiçaria. De acordo com interlocutores Nandeva, as acusações levaram à existência de mais violência física e simbólica na reserva, nas décadas de 1960 e 1970, principalmente contra pessoas Kaiowá e Guarani (Ñandeva) ${ }^{13}$.

De acordo com Mura (2006), na década de 1970, o equilíbrio da reserva mudou, e a família Fernandes perdeu espaço territorial para os terena, sob a liderança de Ramon Machado. Com a divisão territorial da Reserva em duas, sendo uma a aldeia Jaguapirú e a outra a aldeia Bororó, Ramon passou a ser capitão da aldeia Jaguapirú, deixando a aldeia Bororó sob comando de Ireno Snard. Segundo esse autor, o surgimento de Ramon se deveu principalmente devidoao apoio da Missão Caiuá (que lhe entregou um trator) e do chefe do Posto da época, instituições que acreditavam que esse apoio aos Terena contribuiria para o "desenvolvimento da Reserva" (MURA, 2006, p. 333).

Segundo a interlocutora Guarani (Nandeva), "depois que entrou o Ramon Machado e o Chaquinho começou a dividir, por questões políticas". Eles "eram bravos, davam castigos para as pessoas, colocavam as mulheres para trabalharem peladas nas estradas". De acordo com a interlocutora, os novos capitães proibiam a prática da "cultura" dentro da aldeia:

Na época dos Ramon, esses novos capitães, eles proibiram a prática da cultura dentro da aldeia. Impediam os Guarani e Kaiowá achando que eles cantavam à noite e dançando à noite, que eles estavam fazendo macumba. Estavam fazendo reza brava, estavam fazendo feitiçaria, que era coisa do diabo. Proibia. Eles iam nas festas e falavam que os índios Guarani e Kaiowá tinham rezas só para matar. Ou às vezes a pessoa estava cantando na casa e já achavam que estava bêbado. Outro dia chegavam os conselheiros, levavam, não é, pai? Bate. Leva para trabalhar na beira da estrada. Surra ainda.

Na década de 1970, houve uma diminuição do número dos rituais na reserva, principalmente porque havia a ameaça de retaliações e da violência física. Os ñanderú foram perdendo espaço político e religioso na RID. Suas rezas visando à cura foram cada vez menos acreditadas, em um processo de

\footnotetext{
${ }^{13}$ De acordo com um reverendo da Missão Caiuá, em 2007, os pastores da reserva tiveram que assinar um Termo de Ajuste de Conduta junto ao Ministério Público, "para respeitar a cultura": "Essa coisa de não deixar o paciente ir no pajé ou não ir no hospital pra ficar só na igreja, barulho, discriminação - você não pode cumprimentar o outro que não é da tua igreja - essas coisas assim. E tudo botava no TAC pra se respeitar essas coisas, pra se viver harmonicamente aqui dentro".
} carisma de xamãs Kaiowá e Guarani na resenva multiétnica de Dourados, MS (1917-1980) 
perda de prestígio e carisma desses tradicionais chefes de parentela. De acordo com Max Weber (2012, p. 159):

Se, por muito tempo, não há provas do carisma, se o agraciado carismático parece abandonado por seu deus ou sua força mágica e heroica, se lhe falha o sucesso de modo permanente e, sobretudo, se sua liderança não traz nenhum bem-estar aos dominados, então há a possibilidade de desvanecer sua autoridade carismática.

Além disso, os xamãs já não podiam resolver os conflitos entre as parentelas, que eram associados a problemas espirituais.

De acordo a Mura (2006), a partir da década de 1970, houve a expulsão de muitos ñanderú da RID, levando à consequente diminuição do número de rituais "tradicionais" nessa localidade:

[...] segundo informam os Kaiowá, o líder terena, com a ajuda de sua "polícia indígena" teria sido alvo de inúmeras violências e expulsões de líderes políticos e religiosos, chegando a ter, após a morte de Ireno Snard (ocorrido no fim dos anos 80), o pleno controle da reserva. (MURA, 2006, p.333).

Com a expulsão de xamãs Kaiowá e Guarani e o controle da RID, então efetuada por Ramon Machado, criou-se uma diminuição da presença de lideranças políticas e religiosas tradicionais na RID. Dessa forma, muitos habitantes da RID começaram a afirmar que "na reserva não existem mais rezadores de verdade". Sendo assim, amplificou-se a descrença em relação aos rituais e às curas promovidas pelos ñanderú.

Com a redução do número de xamãs Kaiowá e Guarani na RID, os que restaram já não tinham recebido o mesmo preparo e conhecimento como os ñanderú, sendo chamados de caciques ou rezadores. Apesar de também serem líderes carismáticos, os rezadores e rezadoras não possuíam o mesmo reconhecimento como possuíam os ñanderú (MURA, 2006).

No final da década de 1970, os pastores da Missão Caiuá seguiam sendo personalidades carismáticas de importância, mas não atendiam às expectativas dos Kaiowá e Guarani em relação à cura espiritual, considerada como resultado do afastamento dos maus espíritos.

A situação descrita abriu espaço para a entrada de um grande número de igrejas evangélicas pentecostais na Reserva, no começo da década de 1980. Diferente das igrejas protestantes históricas, como a Missão Caiuá, igrejas como a Deus é Amor permitiam aos indígenas tornarem-se pastores sem a cobrança de um profundo estudo teológico (PEREIRA, 2004). No começo da década de 1980, iniciou-se uma nova situação histórica na Reserva, associada à entrada de um amplo número de missões pentecostais e à realização de conversões religiosas em massa a essas igrejas. 


\section{Segundo uma interlocutora Guarani (Ñandeva):}

Depois de muitos anos, já na década de 1980, é que a Missão [Evangélica Caiuá] deixou de colocar as práticas tradicionais guarani kaiowá como se fosse coisa de pecado. Aí eles não pressionaram mais, evoluíram um pouco.

\section{Reflexões finais}

A política indigenista na reserva de Dourados posta em prática pelo SPI e pela FUNAI em associação à MEC atrelou a mudança de costumes e a "civilização" à conversão religiosa, desde a entrada da Missão na Reserva, em 1929. Muitos Kaiowá e Guarani quiseram participar das atividades escolares e religiosas da Missão e fizeram uso da assistência na área de saúde. A sua "conversão" à religião presbiteriana associava-se mais ao vínculo que possuíam com a Missão Caiuá, como uma contrapartida pela ajuda material dada pela Missão.

Estabeleceu-se uma espécie de concorrência entre líderes carismáticos, os pastores da Missão Caiuá e os ñanderú. Os pastores da missão estimulavam os Kaiowá e os Guarani a não participarem dos rituais e das cerimônias religiosas dos Kaiowá e dos Guarani. Entretanto, essas etnias seguiam participando dos dois tipos de rituais.

A situação histórica a partir da década de 1950 até 1980 foi um período de maior transformação econômica e política na reserva, que influenciou na perda do carisma dos ñanderúou rezadores. Devido ao início da derrubada das matas a partir da década de 1950, muitos rituais e interditos já não podiam mais ser praticados.

Com a entrada massiva de parentelas na Reserva nas décadas de 1960 e 1970, e a formação da tríade estabelecida entre chefes de posto, pastores da Missão Evangélica Caiuá e capitães (sobretudo terena), muitos rezadores perderam importância política na Reserva. $\mathrm{O}$ apoio dado pelas agências indigenistas aos capitães legitimava suas ações violentas contra Kaiowás e Guaranis que participavam de rezas tradicionais.

Nessas décadas, como resultado do apoio dado pela MEC às parentelas dos capitães terena e o aumento das rivalidades internas, houve uma amplificação das acusações de feitiçaria entre as parentelas e o aumento da violência simbólica e física contra os Kaiowá e Guarani participantes dos rituais tradicionais.

A perda do carisma de muitos ñanderú e rezadores, no final da década de 1970, foi resultado, por um lado, das consequências da política de terras 
e do confinamento, que inviabilizou a reprodução de muitas práticas sociais tradicionais dentro da Reserva. Por outro lado, a amplificação das acusações de feitiçaria entre parentelas rivais relaciona-se ao discurso da Missão Evangélica, que insistia em afirmar o caráter demoníaco dos rituais organizados pelos ñanderú. A expulsão de muitos ñanderú da Reserva nas décadas de 1960 e 1970 gerou uma situação de crise espiritual, que abriu espaço para a entrada das missões pentecostais na reserva de Dourados, desde o início da década de 1980.

Muitas situações existentes na reserva de Dourados desde o ingresso da MEC, mas, principalmente, no período entre 1960 e 1980, se ocorressem na atualidade, seriam consideradas violações de direitos de liberdade religiosa e intolerância religiosa contra os Kaiowá e os Guarani. Entretanto, na legislação vigente naquele período, que tinha origem na legislação do início da República, o combate à feitiçaria era instituído como uma prática legal e resultou na descriminação em relação às religiões afro-brasileiras e em relação às religiões indígenas.

\section{Referências}

BENITES, Tonico. A escola na ótica dos Ava Kaiowá: impactos e interpretações indígenas. Rio de Janeiro: UFRJ/MN/PPGAS, 2009.

BLOCH, Marc. Apologia da história ou o ofício de historiador. Rio de Janeiro: Jorge Zahar, 2001.

BRAND, Antônio. O impacto da perda da terra sobre a tradição Kaiowá/Guarani: os difíceis caminhos da palavra. Porto Alegre, RS: PUC/RS, 1997.

CARDOSO DE OLIVEIRA, Roberto. Do índio ao bugre: o processo de assimilação dos Terêna. Rio de Janeiro: Francisco Alves, 1976.

GONÇALVES, Carlos Barros. Missionários de papel: imagens dos índios Caiuá em jornais protestantes. In: LANGER, Protasio Paulo; CHAMORRO, Graciela (Org.). Missões, militância indigenista e protagonismo indígena. São Bernardo do Campo, SP: Nhanduti, 2012. 368p. v. II.

LOCKE, John. Carta a respeito da tolerância. São Paulo: IBRASA, 1964[1689].

LOURENÇO, Renata. A política indigenista do Estado Republicano junto aos índios da Reserva de Dourados e Panambizinho na área da educação escolar (1929 a 1968). Dourados, MS: UEMS, 2008.

MIRANDA, A. P. M. Entre o privado e o público: considerações sobre a (in) criminação da intolerância religiosa no Rio de Janeiro. Anuário Antropológico, Brasília, 2009/ II, p. 125-152, dez. 2010. 
MIRANDA, A. P. M.; GOULART, J. B. Combate à intolerância ou defesa da liberdade religiosa: paradigmas em conflito na construção de uma política pública de enfrentamento ao crime de discriminação étnico-racial-religiosa. In: ENCONTRO ANUAL DA ANPOCS, 33., 26-30 out. 2009, Caxambu, MG. Anais... Caxambu: ANPOCS, 2009.

MURA, Fabio. À procura do "bom viver": território, tradição de conhecimento e ecologia doméstica entre os Kaiowá. Rio de Janeiro: UFRJ/MN/PPGAS, 2006.

A trajetória dos Chiru na tradição de conhecimento Kaiowá. Mana,Rio de Janeiro, v. 16, n. 1, p. 123-150, 2010.

MARQUES, Levi Pereira. Significados do processo de conversão dos Kaiowá e Guarani ao pentecostalismo e sua inserção no cenário de inovação cultural. In: LANGER, Protasio Paulo; CHAMORRO, Graciela (Org.). Missões, militância indigenista e protagonismo Indígena. São Bernardo do Campo, SP: Nhanduti, 2012. 368 p. v. II.

. O pentecostalismo Kaiowá: uma aproximação dos aspectos sociocosmológicos e históricos. In: WRIGHT, Robin M. (Org.). Transformando os deuses: igrejas evangélicas, pentecostais e neopentecostais entre os povos indígenas no Brasil. Campinas, SP: Editora da Unicamp, 2004. v. II.

RICOEUR, Paul. La memoria, la historia, el olvido. Madrid: Editorial Trotta, 2003.

SHADEN, Egon. Aspectos fundamentais da cultura guarani. São Paulo: Difusão Europeia do Livro, 1962.

SILVA, Jorge da. Guia de luta contra a intolerância religiosa e o racismo. Rio de Janeiro: CEAP, 2009.

SOUZA, Ana Maria Melo. Liderança Kaiowá: entre a religião tradicional e a Igreja pentecostal. In: LANGER, Protasio Paulo; CHAMORRO, Graciela (Org.). Missões, militância indigenista e protagonismo indígena. São Bernardo do Campo, SP: Nhanduti, 2012. 368p.v. II.

THOMAZ DE ALMEIDA. Do desenvolvimento comunitário à mobilização política:o Projeto Kaiowa-Ñandeva como experiência antropológica. Rio de Janeiro: Contra Capa, 2001.

VIETTA, Katya. Histórias sobre terras e xamãs Kaiowá: territorialidade e organização social na perspectiva dos Kaiowá de Panambizinho (Dourados, MS) após 170 anos de exploração e povoamento não indígena da faixa de fronteira entre Brasil e Paraguai. 2007. 512f. Tese (Doutorado em Antropologia Social) - Universidade de São Paulo (USP), São Paulo, SP.

VIETTA, Katya; BRAND, Antônio. Missões Evangélicas e Igrejas Neopentecostais ente os Kaiowá e os Guarani em Mato Grosso do Sul. In: WRIGHT, Robin M. Transformando os deuses: igrejas evangélicas, pentecostais e neopentecostais entre os povos indígenas no Brasil. Campinas, SP: Editora da Unicamp, 2004. v. II.

VIVEIROS DE CASTRO, Eduardo. A inconstância da alma selvagem - e outros ensaios de antropologia. São Paulo: Cosac Naify, 2013.

WEBER, MAX. Economia e sociedade - elementos da sociologia compreensiva. 4. ed. 1. reimp. Brasília: Editora da Universidade de Brasília, 2012. v. 1. carisma de xamãs Kaiowá e Guarani na resenva multiétnica de Dourados, MS (1917-1980) 


\section{Documentos:}

Entrevista com Marlene Guarani, aldeia Jaguapirú, março de 2010.

MISSÃO EVANGÉLICA CAIUÁ - MEC. Associação Evangélica de Catequese dos Índios. Biblioteca Marechal Rondon. Rio de Janeiro: Museu do Índio/FUNAI, [s.d.].

SERVIÇO DE PROTEÇÃO AO ÍNDIO - SPI.Sobre ministração de escola e cultos religiosos, 1953. Microfilme 380, fotograma 1507.

Separata do regulamento do Serviço de Proteção aos Índios relativa aos Postos Indígenas - decreto n. 736 de 5 de abril de 1936.Microfilme 338, fotograma 2274b. p.15.

SUMMER INSTITUTE OF LINGUISTICS. Relatório das atividades dos membros do "Summer Institute of Linguistics" entre os indios brasileiros no ano de 1959, dirigido ao diretor do Serviço de Proteção aos Índios. Rio de Janeiro: Museu do Índio/FUNAI. Microfilme 338, fotograma 881-893, 1960.

Recebido em 28 de julho de 2014

Aprovado para publicação em 20 de maio de 2015 